
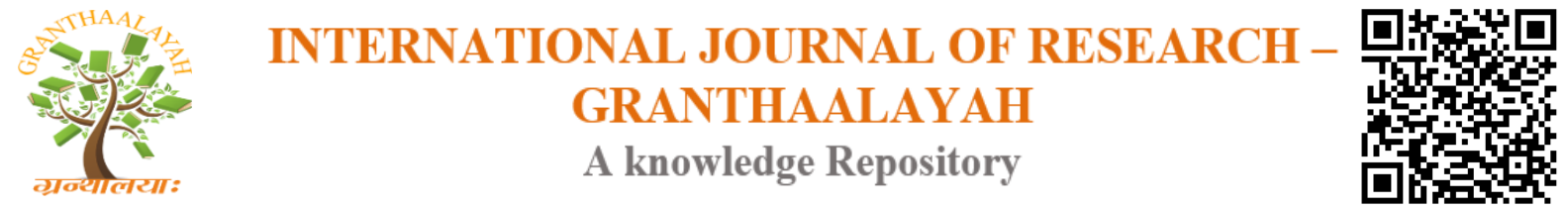

Science

\title{
PAMCA KOŚAS AND THE GANAPATI - ANNAMAYA KOŚA, AND ITS ROLE IN MANAGING HEALTH AND THE IMMUNE SYSTEM WITH SPECIAL REFERENCE TO HIV/AIDS
}

\author{
Harichandra $^{1}$, Ramesh M.N. ${ }^{* 2}$ \\ ${ }^{1}$ S-VYASA, Kempegowda Nagara, Bengaluru, India \\ *2 Molecular Biology Laboratory, S-VYASA, India
}

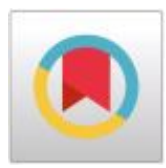

\begin{abstract}
Pamca kośas are the sum and substance of a being. Annamaya kośa is the grossest of the pamca kośas. This paper deals with the annamaya kośa, and the message of the purānik character Ganapati in managing health and the immune system with special reference to HIV/AIDS. The paper starts with explaining the need for knowledge and explaining why the purānik stories were required and what they aimed at. Keeping in mind that purānik characters are symbolism of some concept, the paper explores the connection between Ganapati and the food, which is the maker of annamaya kośa. In the later part the paper, with the help of several references the paper explains the significance of food (nutrition) in managing, health and the immune system with special reference to HIV/AIDS.
\end{abstract}

Keywords: HIV/AIDS; Gaṇapati; Panchakośa; Annamaya Kośa; Malnutrition.

Cite This Article: Harichandra, and Ramesh M.N.. (2017). "PAMCA KOŚAS AND THE GANAPATI - ANNAMAYA KOŚA, AND ITS ROLE IN MANAGING HEALTH AND THE IMMUNE SYSTEM WITH SPECIAL REFERENCE TO HIV/AIDS.” International Journal of Research - Granthaalayah, 5(7), 262-269. 10.29121/granthaalayah.v5.i7.2017.2132.

\section{Introduction}

Everyone wants to be knowledgeable. The English word 'knowledge' refers to two Indian words, (1) the 'jnāna' and (2) the 'vidya'. Vidya is something that we learn from the outside world. Jnāna is what we learn within ourselves through a process called spirituality.

Vidya is earned through the sense organs; as the sense organs interact with nature, institutions, peers, books, or anybody / anything else. In an attempt to gain vidya, the sense organs work within the velocity of light. The fastest of these senses are the eyes which work below the velocity or light or at the velocity of light. Hence the amount of vidya learnt in one's life's time is limited. The story of Bhāradvāja who took births after births to learn Vedas, the vidya route; and later realized that he needs thousands of births to learn completely, is worth noting here(Azzarito 2015). On the other hand, Jnāna is obtained when we travel inwards; within us 
through a process called tapas or spirituality, where we surpass the velocity of light from within. Hence that which is learned through jnanna route is unlimited.

Jnāna requires tremendous amount of effort, the 'sädhana'. People who attain jnāna are called the jnānis or the dārshaniks. While with no barriers of caste, creed, colour, country, gender or whatsoever everyone can become a jnāni, it is not an easy sädhana to become a jnāni. Only a few people can make it up. These few jnānis, in the interest of upliftment of the society propagated the knowledge they gained through various forms. The highest form of knowledge are the Vedas. Over time, common man felt it difficult to understand even the Vedas, and hence came the various simpler explanations for the Vedas (Swaminathan 2016) in the form of Darshanas, Upanishads etc.

To further ease the understanding of the concepts, stories called the purānas came up. The personified characters in the purānas, their form and their activities either explained certain concepts of the world, or pass on certain messages for upliftment of humanity at large; all of which are available in a seed form in the higher Vedic literature. Hence purānik characters further elaborate the concepts in their higher forms the Upanishads, the Vedas etc. for understanding by the common man. One of such purạnik characters is the 'Ganapati'. The Ganapati can be looked at in several dimensions. As such, the concepts explained in the Vedic literature can be understood in three dimensions, or can be applied to three levels:

1) Adhibhoutika : Applicable to the brahmānda (solar system)

2) Adhidaivika: Applicable to the human pindānda (body)

3) Ádhyātmika: Applicable to the âtma (soul)

Macrocosm, or the solar system including all the nature surrounding us is called the brahmämda. Application of Vedic knowledge to the brahmäm $\dot{d a}$ is the ädibhoutika approach. Microcosm refers to the pindānda or an individual. Yajur Veda says "yat brahmāimde, tat pinde", which means as is the solar system, so is the individual. This further means that the governing principles applicable to brahmāmda are also applicable to pindānda. Thus Vedic literature is applicable to both brahmāmịda and piṇ̂aṇ̣

Soul is the sum and substance of the microcosm. Hence, as is the body so is the soul. Hence the Vedic literature as applicable to the $\bar{a} t m a$ is referred to as the $\bar{a} d y \bar{a} t m i k a$ approach.

The soul has five layers of existence or the five components, as the macrocosm is made of the five elements, the panchabutas. They are the annamaya kośa, prānamaya kośa, manomaya kośa, vijñānamaya kośa and ānandamaya kośa. Table 1 gives an overview of the three dimension of understanding of the Vedic literature.

Table 1: Three dimensions of understanding of the Vedic literature

\begin{tabular}{|c|c|c|c|}
\hline $\begin{array}{l}\text { Level : Based on } \\
\text { Embodied } \\
\text { energies* }\end{array}$ & $\begin{array}{l}\text { Adhibhoutika } \\
\text { (brahmāmda) } \\
\text { Macrocosm }\end{array}$ & $\begin{array}{l}\text { Adhidaivika (Pindānda) } \\
\text { Microcosm }\end{array}$ & $\begin{array}{l}\bar{A} d h y \bar{a} t m i k a \\
(A n \underline{d} \bar{a} n \underline{d} d a / \bar{A} t m a) \\
\text { Soul }\end{array}$ \\
\hline 1 & Earth & Physical body & Annamaya kośa \\
\hline 2 & Atmosphere & Prāṇik body & Prāṇamaya kośa \\
\hline 3 & Moon & Mind & Manomaya kośa \\
\hline 4 & Other planets and their & (Budha), & Vijñānamaya kośa \\
\hline
\end{tabular}




\begin{tabular}{llll}
\hline & energies (Grahās) & $\begin{array}{l}\text { understanding } \\
\text { vision (Ś } u k r a), \text { etc. }\end{array}$ & \\
$\mathbf{5}$ & Surya (Sun) & Soul & Anandamaya kośa \\
\hline
\end{tabular}

* In a relative ascending scale of 1 to 5 .

Annamaya kośa is the grossest of the layers of existence. While there are several approaches with which people have tried to understand and apply Ganapati to, this articles takes the approach of the panchakośa concept explained elaborately in the Taittareya Upanishad. In particular, at the ädhidaivika level. Further, this paper only discusses Ganapati at the annamaya kośa layer of existence.

The hypothesis, this paper is centred around is that, 'Ganapati is the Lord of food', which is the most significant 'maker' of the annamaya kośa. This article attempts to prove the hypothesis based on several simple observations on the form of Ganapati and the ritual of Ganapati pūjā.

\section{Ganapati, The Lord of Food}

Human beings at the time of birth weights anywhere between 2.5 $\mathrm{kg}$ to $4 \mathrm{~kg}$. As they grow, normally adults reach between $50 \mathrm{~kg}$ to $100 \mathrm{~kg}$, or even more. This add-on of the weight is mainly due to the food we eat. Thus we can comfortably attribute the physical body (annamaya kośa) to the food; and thus can also be comfortably attributed to the basic causing factor (käraka) of annamaya kośa. Fig. 1 shows a typical Gaṇapati.

Ganapati is said to be the son Pārvati. Pārvati symbolizes water. As such, Pārvati is the daughter of Parvata Rāja (Mountains' king)

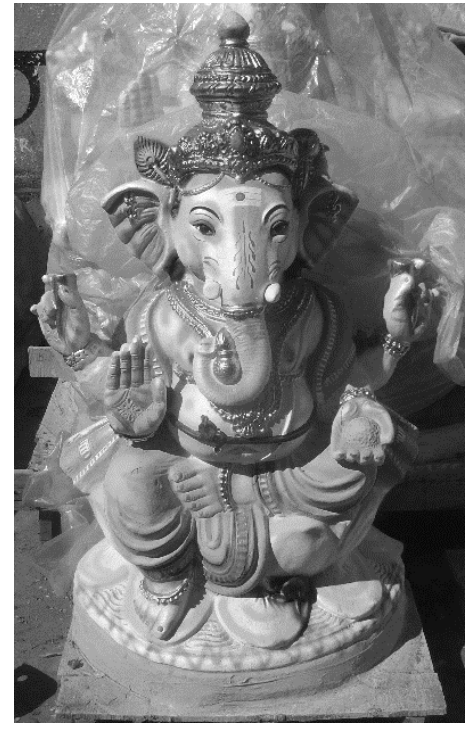

Figure 1: Gaṇapati (Photograph by Author) (Ramachander n.d.), meaning the daughter of the king of hills, which further means birth of Pārvati is caused by hills. It is known that as clouds are moving, when they encounter hills. This encounter leads to fall of rain. This is symbolized as Pārvati.

Food is a product of earth and water. As such the dirt from Pārvati's body was used to make Ganapati, the story says. Dirt from Pārvati's body is nothing but the dirt carried by water as it flows. The leaves, the twigs etc. carried by water as it flows is the dirt, which is a source of manure. From manure grows the food. Hence Pārvati created Ganapati with the dirt of her body.

The word gana means people. Pata means path. Hence Ganapati is the one who takes the people in the right path and protect them. Pati is one who takes people on the right path and protect them. Thus Ganapati means the protector of the people. That would mean, a king/lord. The basic duty of the king is to facilitate the basic needs of the people. The inevitable basic need of the people is the 'food'. Hence Ganapati is the lord of food. Let us see some of the features of Ganapati. 
Fat stomach: Ganapati has a fat stomach. This form symbolizes that Ganapati has enough food to feed everyone. Fig. 2 shows a fat stomach of Ganapati.

Snake around the belly: Further, food is a treasure. Everyone needs it. In order to guard this treasure called food, Ganapati has a snake wound around his stomach. Fig. 2 shows a snake tied around the fat stomach of Ganapati.

Rat as vehicle: Rats are notorious, especially for the farmers. They are like pests in the fields and spoil, eat and contaminate the crops, fruits, vegetables, cereals, oilseeds or whatsoever. Hence control over the rats is important to avoid spoiling of

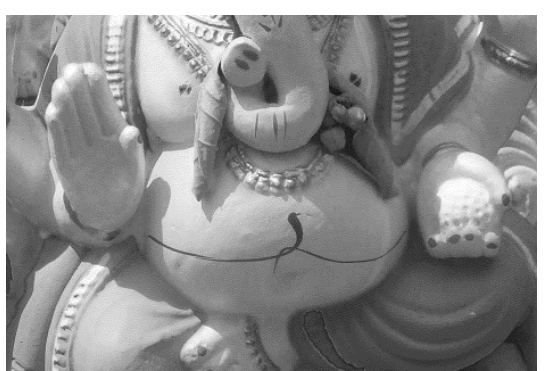

Figure 2: Gaṇapati - Fat belly with snake tied around (Photograph by Author) food. Hence, Ganapati rides over the rate, with a whip symbolizing its control. The snake around the stomach also have the role of keeping rats under control. Fig. 3 shows Ganapati being seated on a rat.

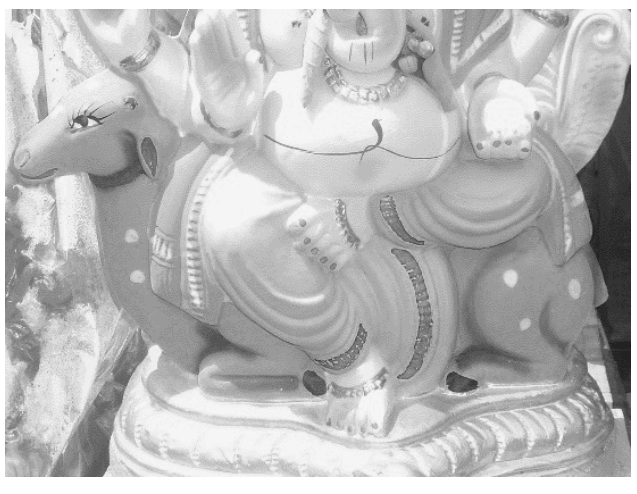

Figure 3: Gaṇapati - Riding on the rat. (Photograph by Author)

work, which is essentially a hurdle.

If a person avoids Ganapati pūjā his works would face lot of hurdles, which means that if one does not have food, he cannot do work, cannot involve properly in work, and has to face hurdles in work.

Pillari: Added to the above coincidences is the Pillari which further supports the hypothesis that Ganapati is lord of food. The Pillari is said to be the true original or root form of Ganapati. During the Ganapati festival on Bādrapada cauti $\left(4^{\text {th }}\right.$ day from the new moon day), before doing $p \bar{u} j \bar{a}$ for the elephant faced form of Ganapati, the 'Pillari' is first offered the püjā. Pillari is basically cow dung in the shape of a cone with a little grass pierced into the apex of the cone. Grass indicates the vegetation, which is the source of food. Grass family is the family of vegetation where we get the basic/staple food,

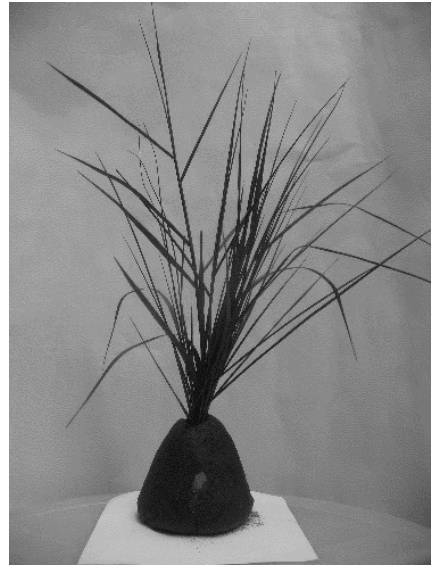

Figure 4: Pillari

(Photograph by Author) 
the rice, ragi, jowar, wheat etc. Cow dung being one of the best manures on earth, the grass comes out of the manure, which is what is indicated in Pillari. Fig. 4 show Pillari.

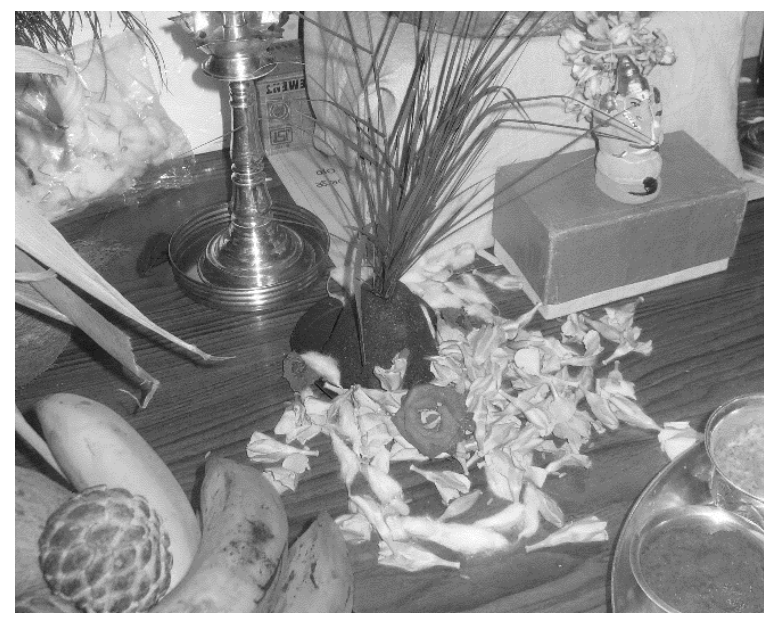

Figure 5: First pūjā for Pillari (Photograph by Author)
Sometimes turmeric is used in place of cow dung. Turmeric indicates protection. Since growth of vegetation requires both nutrition (given by cow dung) as well as protection, it is a practice that some use turmeric to make the conical form. Fig.5 shows $p \bar{u} j \bar{a}$ having already been performed during the Ganapati festival on the $4^{\text {th }}$ Day of the Bhadrapada month, for Ganapati in the form of Pillari before doing the $p \bar{u} j \bar{a}$ for the typical Gaṇapati form.

Pūjā with leaves: Also, unlike any other pūjā for various gods, all kinds of green leaves are used during Gaṇapati pūjā which indicates vegetation. Figure 6 shows offering of leaves to Ganapati during Gaṇapati pūjā.

Baski or sit-ups: Another interesting coincidental practice to support the current hypothesis is performing sit-ups after the traditional Ganapati Pūjā. Compared to several other festivals and $p \bar{u} j \bar{a} \mathrm{~s}$, that are performed, one thing special about the Ganapati püjā is performing 'Baski', a

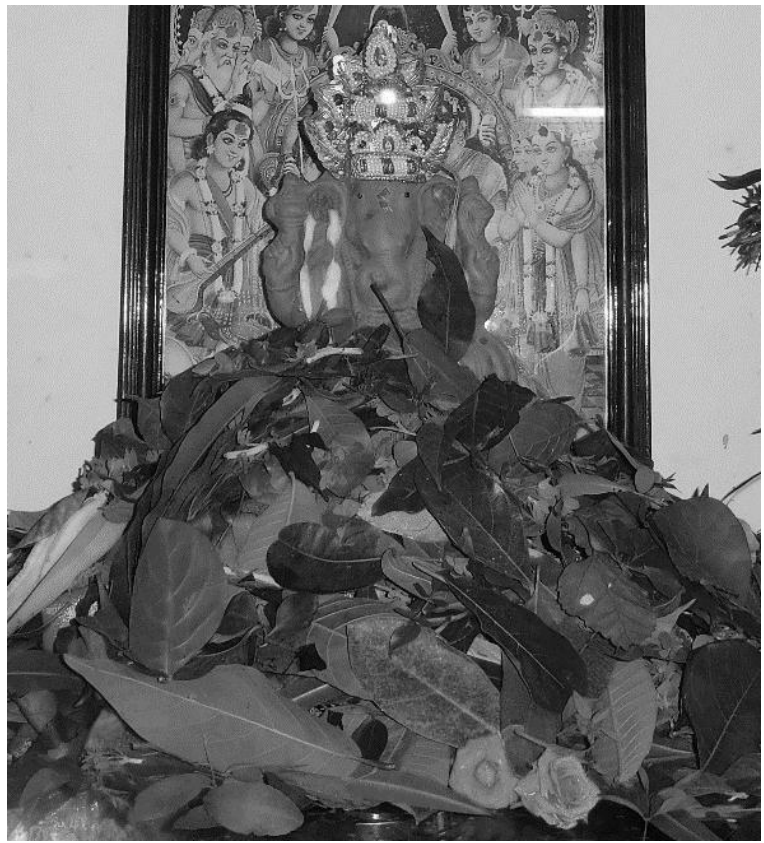

Figure 6: Offering of varieties of leaves to Gaṇapati (Photograph by Author)

Heaps of a variety of leaves during Gaṇapati pūjā form of exercise with repeated sit-ups with hands crossed and holding the ears. This exercise is done after Ganapati $p \bar{u} j \bar{a}$. This symbolizes that after taking food one should work well to digest the food that is consumed.

Modaka: Modaka is a food that is said to be liked to most by Ganapati. Modaka is a sweet food that has an outer covering made of rice, and the actual sweet within it. The staple food basically comes in this form; a covering outside, and the actual food inside (Example: Rice and the paddy). Also, modaka (the sweet) means glucose. It is the desire of Ganapati that, whatever one has consumed as food, it is to be converted into glucose. Hence, Ganapati wishes for modaka; which means Ganapati wishes that the food we eat is converted into glucose.

Tulsi and Ganapati: The following is yet another interesting thing: Tulsi (Ocimum Sanctum) is not accepted for $p \bar{u} j \bar{a}$ in a Gaṇapati temple(Iyengar et al. 2015). Tulsi has highly 
medicinal values and helpful in curing several diseases(Joshi et al. 2011; Gupta et al. 2002; Prakash \& Gupta 2005). Of several reasons, this is also another reason why a plant of Tulsi is kept in front of every Indian home. There is a saying 'one who knows his food, does not have a disease'. Since a person doing Ganapati püjā rightly, does not become a victim of any disease. Hence, Tulsi is not required. As such, bringing Tulsi to Ganapati temple is an insult to Ganapati. Hence, Tulsi is not accepted for püjā in Gaṇapati temples.

With all the above correlations between the form of Ganapati, practices during and after Ganapati $p \bar{u} j \bar{a}$ it is quite evident that Gaṇapati is a symbolic purānik character, and is the lord of food; and Gaṇapati pūjā means having 'adequate and proper' food.

\section{Nutrition \& HIV/AIDS}

Food, is the basic inevitable need of one and all. Lack of good quality and quantity of food leads to malnutrition. Malnutrition has been a global problem. 925 million people do not have enough to eat and 98 percent of them live in developing countries (FAO 2010). It is so unfortunate that when we call today's world as the world of advancements, the world of science and technologies; with all the developments, we are unable to manage providing the basic need for all, the food by adopting suitable strategies. Quite obviously the state of health of these people with malnutrition have to face basic health problems, and with the body's defense mechanism not nourished, they are prone to several opportunistic diseases.

To give an analogy, any country's defence personnel (say, soldiers) guard the country from enemy's attack. It is a common sense that if these soldiers are not given food, the strength and the number of the soldiers reduces. Hence they will not be able to guard the country. On similar lines, it is a common sense that the number and the strength of the antibodies produced upon attack by harmful/poisonous agents depend upon the food a person takes. Hence, malnutrition (undernutrition) is a severe deficiency. Because of the deficiency the bodily dysfunction occurs and body becomes increasingly vulnerable, leading to infection of the host (Enwonwu, C 2006). Chandra $\mathrm{R} \mathrm{K}$ makes is clear that malnutrition is the most common cause of immunodeficiency worldwide (Chandra 1991).

Children with malnutrition also have loss of the ability of killer lymphocytes to recognize and destroy foreign tissues (Enwonwu, C 2006). Malnutrition results in deficiency of macronutrients. A chronic deficiency of macronutrients lead to protein energy malnutrition(Morley 2007). Particularly in children, protein energy malnutrition is known to cause widespread atrophy of lymphoid tissues, particularly T-lymphocyte areas(Kumar et al. 2004). This leads to impairment of antibody production to T-dependent antigens. This further causes impairment in adaptive immunity and leads to reduced ability of the patients to ward off infections (Chandra 1999).

Malnutrition is considered to be a marker for poor prognosis among subjects infected with HIV (Nerad et al. 2003).

Nutritional management is considered to be an integral part of care for subjects infected with human Immunodeficiency Virus (HIV) (Nerad et al. 2003). 
In both malnutrition and HIV there is reduced CD4 and CD8 T-lymphocyte numbers (Chandra 1999). CD4 and CD8 being the markers for HIV, malnutrition and HIV and coincidental and providing proper nutrition helps increase CD4 and CD8, and thus help fighting HIV.

Rosenberg et al. [9] observed that HIV-specific CD4+ T-cell responses were of high magnitude in individuals who were HIV infected but not showing progression over long periods (long-term nonprogressors). Also, in acute viral infections such responses could be seen but they were generally not present in patients with chronic progressive infections.

Along with education and counselling nutritional support is also on focus in improving the QOL of people living with HIV/AIDS. It is also to be noted that malnutrition further reduces the capacity of the body to fight infection. This is because of compromise of various immune parameters. Incorporating components of nutrition and its management goes a long way in improving QOL, and better survival in HIV-infected subjects (Duggal et al. 2012).

Hence, proper nutrition is the basic necessity for a person to keep themselves away from not only deadly diseases like HIV/AIDS, but also any disease for that matter.

As also, the first step in prevention, control and cure of AIDS is Ganapati pūjā. Here, Gaṇapati pūjā does not mean offering flower or garlands to the idol of Ganapati. Ganapati is the lord of food, product of light. Ganapati pūjā means the pūjā for the stomach. Again, pūjā for the stomach does not mean garlanding or offering flowers for the stomach; but having food for the stomach.

\section{Conclusion}

Puranic characters symbolize the aspects of working of the human body, the nature and help people understand the real purpose of life, explained in the vedas. Ganapati is a character which symbolizes one of the important aspects of working of the human body, the providing of proper nutrition which is the first step in the development of the panchakoshas. Proper nutrition is key to maintaining proper immune system, and inevitable to manage immune system and is specifically important for subjects with HIV.

\section{References}

[1] Azzarito, K., 2015. The yoga pose bharadvajasana is a seated twist named after the sage Bharadvaja. Share Yoga. Available at: http://www.shareyoga.com/yoga/finding-your-purposethe-story-of-bharadvaja/ [Accessed July 3, 2017].

[2] Chandra, R.K., 1999. Nutrition, infection and immunity: Nutrition and immunology: from the clinic to cellular biolagy and back again. In Proceedings of the Nutrition Society. pp. 681-683.

[3] Chandra, R.K., 1991. Nutrition and immunity: lessons from the past and new insights into the future. The American Journal of Clinical Nutrition, 53(5), pp.1087-1101.

[4] Duggal, S., Chugh, T. Das \& Duggal, A.K., 2012. HIV and malnutrition: Effects on immune system. Clinical and Developmental Immunology, 2012.

[5] Enwonwu, C, O., 2006. Complex interactions between malnutrition, infection and immunity: relevance to HIV/AIDS infection. Nigerian Journal of Clinical and Biomedical Research, 1(1), pp.6-14. 
[6] FAO, 2010. Global hunger declining, but still unacceptably high. FAO news release, (September).

[7] Gupta, S.K., Prakash, J. \& Srivastava, S., 2002. Validation of traditional claim of Tulsi, Ocimum sanctum Linn. as a medicinal plant. Indian Journal of Experimental Biology, 40(7), pp.765-773.

[8] Iyengar, S., Sapru, T. \& Gupta, A., 2015. Traditional worshipping and conservation of plants. International Journal of Research - Granthaaalayah, 3(9:SE), pp.3-7.

[9] Joshi, B. et al., 2011. Phytochemical extraction and antimicrobial properties of different medicinal plants: Ocimum sanctum ( Tulsi ), Eugenia caryophyllata ( Clove ), Achyranthes bidentata ( Datiwan ) and Azadirachta indica ( Neem ). J Microbiol Antimicrob, 3(1), pp.1-7. Available at: http://www.academicjournals.org/JMA/PDF/pdf 2011/January/Joshi et al.pdf.

[10] Kumar, A. et al., 2004. Nuclear factor-kappaB: its role in health and disease. Journal of molecular medicine (Berlin, Germany), 82(7), pp.434-448.

[11] Morley, J.E., 2007. Protein-energy malnutrition definition. In The Merck Manual of Diagnosis and Therapy. Merck \& Co., USA, p. 2007.

[12] Nerad, J. et al., 2003. General nutrition management in patients infected with human immunodeficiency virus. Clinical infectious diseases: an official publication of the Infectious Diseases Society of America, 36(Suppl 2), pp.S52-S62.

[13] Prakash, P. \& Gupta, N., 2005. Therapeutic Uses of Ocimum Sanctum Linn (Tulsi) With a Note on Eugenol and Its Pharmacological Actions: a Short Review. Indian J Physiol Pharmacol, 49(2), pp.125-131.

[14] Ramachander, P.R., Rama Krutha Parvatha Vardhinyashtakam. Hindupedia. Available at: http://www.hindupedia.com/en/Rama_Krutha_Parvatha_Vardhinyashtakam [Accessed May 21, 2017].

[15] Swaminathan, M., 2016. Samskaras, the vedic perspective of nutrition and learning. In Essen Bildung - Konsum. Springer Fachmedien Wiesbaden, pp. 169-176.

*Corresponding author.

E-mail address: ramesh.mavathur@ svyasa.org 